5. Kucheruk, M.D. (2018). Mikrobiolohichne ta sanitarno-hihiienichne znachennia eubiozu kyshechnyka produktyvnykh tvaryn [Microbiological and sanitary-hygienic value of eubiosis of intestines of productive animals]. Ukrainian Journal of Ecology [in Ukrainian].

6. Cicenia, A. (2013). Postbiotic activities of Lactobacilli-derived factors Journal of Clinical Gastroenterology [Postbiotic activities of Lactobacilli-derived factors Journal of Clinical Gastroenterology]. Rome: New Foods Meeting Held In Rome [in Italian].

7. Kaloev, B. (2002). Molochnokyslye preparaty kak sredstvo ozdorovlenyia tsypliat [Lactic acid preparations as a means of improving chickens]. Lviv: DNDKI veterynarnykh preparativ ta kormovykh dobavok [in Ukrainian].

8. Rolfe, R.D. (2000). The role of probiotic cultures in the control of gastrointestinal health [The role of probiotic cultures in the control of gastrointestinal health]. Oxford: University of Oxford.

\title{
УДК 636.09:616.9:616-07
}

DOI: $10.31073 /$ vet_biotech34-12

ПИСКУН А.В. ${ }^{1}$, канд. вет. наук, e-mail: anton_piskun@ukr.net, УХОВСБКИЙ В.В. ${ }^{2}$, д-р вет. наук, e-mail: uhovskiy@ukr.net, АЛСКСЕСВА Г.Б. ${ }^{1}$, канд. вет. наук, e-mail: serolog@i.ua, СПИРИДОНОВ В.Г.2, д-р с.-г. наук, е-mail: spyrydonov@ukr.net, ПИСКУН О.О.1, канд. вет. наук, e-mail: stepnahelen@gmail.com ${ }^{1}$ Державний науково-дослідний інститут з лабораторної діагностики та ветеринарно-санітарної експертизи

${ }^{2}$ Інститут ветеринарної медицини НААН

\section{РОЗРОБКА ІМУНОФЕРМЕНТНОЇ ТЕСТ-СИСТЕМИ ДЛЯ ДІАГНОСТИКИ ЛЕПТОСПІРОЗУ ТВАРИН}

У статті представлені результати щзодо валідації твердофазної імуноферментної тест-системи для діагностики лептоспірозу серед собак, свиней та ВРХ, щэо була розроблена на базі лабораторії лептоспірозу сільськогосподарських тварин з музеєм мікроорганізмів Інституту ветеринарної медицини (IВМ НААН) та Української лабораторії якості та безпеки продукиії АПК (УЛЯБП АПК).

У ході валідації нами було здійснено кілька технологічних етапів. На першому із них проводили підбір та визначали оптимальні конщентрації і титри основних компонентів ІФА (антигену, імуноферментного кон'югату, ферментного субстрату та блокуючої речовини), а на другому - здійснювали статистичну обробку отриманих результатів після випробування IФА на внутрішньовиробничій панелі проб сироваток крові.

Ключові слова: лептоспіроз, реакція мікроаглютинації, твердофазний імуноферментний аналіз, валідація, титр.

Вступ. Лептоспіроз є одним із найбільш розповсюджених і значимих у соціально-економічному відношенні зоонозів природної осередковості на п’яти континентах (крім Антарктиди) у більшості країн світу [1].

Широкий спектр симптомів за даного зоонозу значно ускладнює клінічний діагноз і робить його ненадійним, тому на перший план виходять лабораторні методи досліджень, а саме серологічні [2]. На сьогодні найбільш широко для діагностики лептоспірозу як у тварин, так і у людей використовується реакція 
мікроаглютинації (РМА) $[3,4]$. Цей метод має багато плюсів, але є і суттєві недоліки, головним із яких є потреба у постійному культивуванні лептоспір, що створює ризик зараження лабораторного персоналу [5]. Тому, хоча PMA і $є$ «золотим стандартом» за діагностики лептоспірозу, враховуючи підвищену увагу світової спільноти до аспектів біобезпеки та біозахисту, останнім часом у ветеринарних закладах різних країн світу все частіше починають використовувати варіанти імуноферментного аналізу (ІФА) [4-6].

На базі лабораторії лептоспірозу сільськогосподарських тварин з музеєм мікроорганізмів IBM НАAН була розроблена тест-система IФА, спрямована на виявлення лептоспірозних антитіл у сироватках крові ВРХ. У якості антигену був запропонований інактивований серовар wijnberg серогрупи Icterohaemorrhagiae. Однак вона так і не набула широкого застосування серед фахівців ветеринарної медицини і потребувала, як і РМА, роботи із патогенною культурою лептоспір [7].

Враховуючи вищесказане, метою нашої роботи було розробити модифікацію імуноферментної тест-системи для діагностики лептоспірозу тварин, що відповідала б таким вимогам:

- здатність виявляти антитіла до всіх серогруп лептоспір, що рекомендовані для діагностики цього зоонозу на території України (мати високу чутливість та специфічність);

- максимально знизити ризик інфікування обслуговуючого персоналу під час приготування реактивів для ІФА та його постановки.

Матеріали і методи досліджень. У ході валідації імуноферментної тестсистеми нами було здійснено кілька технологічних етапів. На першому з них здійснювали підбір та визначали оптимальні концентрації і титри основних компонентів ІФА, а на другому - проводили статистичну обробку отриманих результатів.

Титрування компонентів та порівняння їх ефективності проводили із використанням польових позитивних і негативних за РМА проб сироваток крові собак, свиней та ВРХ, а також семи референс-сироваток (МЕБ), що були отримані із Королівського Тропічного інституту, м. Амстердам.

Дослідження виконували на базі лабораторії лептоспірозу сільськогосподарських тварин з музеєм мікроорганізмів Інституту ветеринарної медицини (IBM НАAН), лабораторії «Науково-дослідного навчального центру діагностики хвороб тварин» IBM НААН та Української лабораторії якості та безпеки продукції АПК (УЛЯБП АПК).

Результати досліджень та їх обговорення. 3 огляду на поставлені вимоги до тест-системи, нами було прийнято рішення використовувати у якості антигену рекомбінантний білок LipL 32, що являє собою модифікований аналог одного із найбільших ліпопротеїнів зовнішньої мембрани лептоспір [8]. Експериментально доведено, що цей білок входить до складу зовнішніх мембран лише патогенних мікроорганізмів L. interrogans роду Leptospira i, що дуже важливо, $є$ безпечним у використанні та виключає інфікування обслуговуючого персоналу лептоспірозом під час роботи із ним $[8,9]$. Все це сприяе його широкому використанню за постановки діагностикумів на лептоспіроз у різних країнах світу $[10,11]$. 
Для визначення оптимальної сенсибілізуючої дози антигену проводили його сорбцію у різних кількостях, від 0,5 до 4 мкг/лунку, на карбонатнобікарбонатному буфері (КББ) зі значенням $\mathrm{pH} 9,6$. Одночасно нами були випробувані речовини, що усували неспецифічну взаємодію антитіл 3 антигеном. У такій якості були апробовані харчова желатина та сухе знежирене молоко (відповідно, $0,5 \%$ та $5 \%$ розчини). Це поєднання не призводить до отримання хибних результатів реакції та дозволяє зменшити затрати часу на титрування компонентів. Результати титрування антигену із різними блокуючими речовинами показано на рис. 1 та рис. 2.

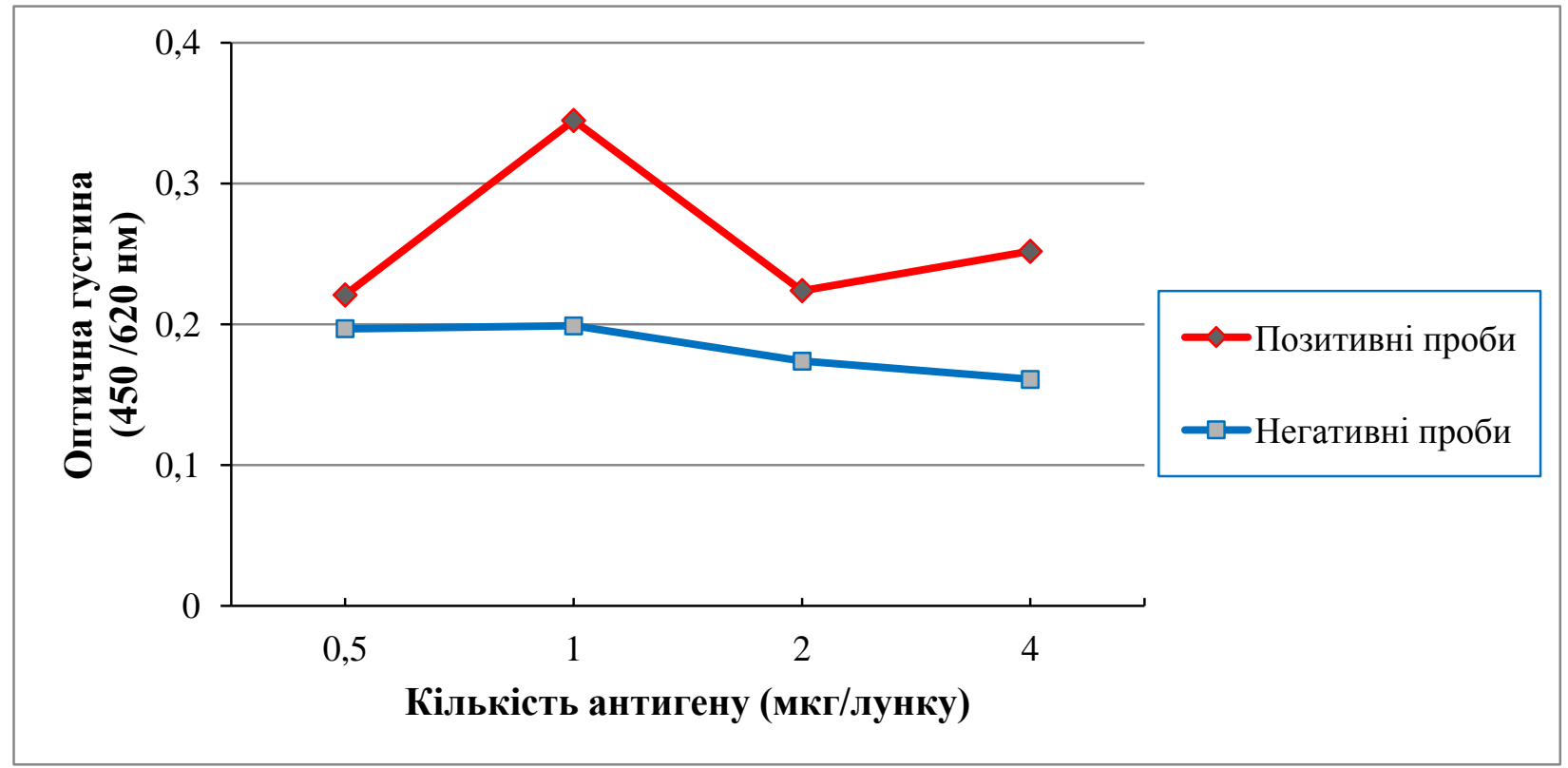

Рис. 1. Крива сорбції антигену на полістиролових мікропланшетах за використання $5 \%$ розчину сухого знежиреного молока

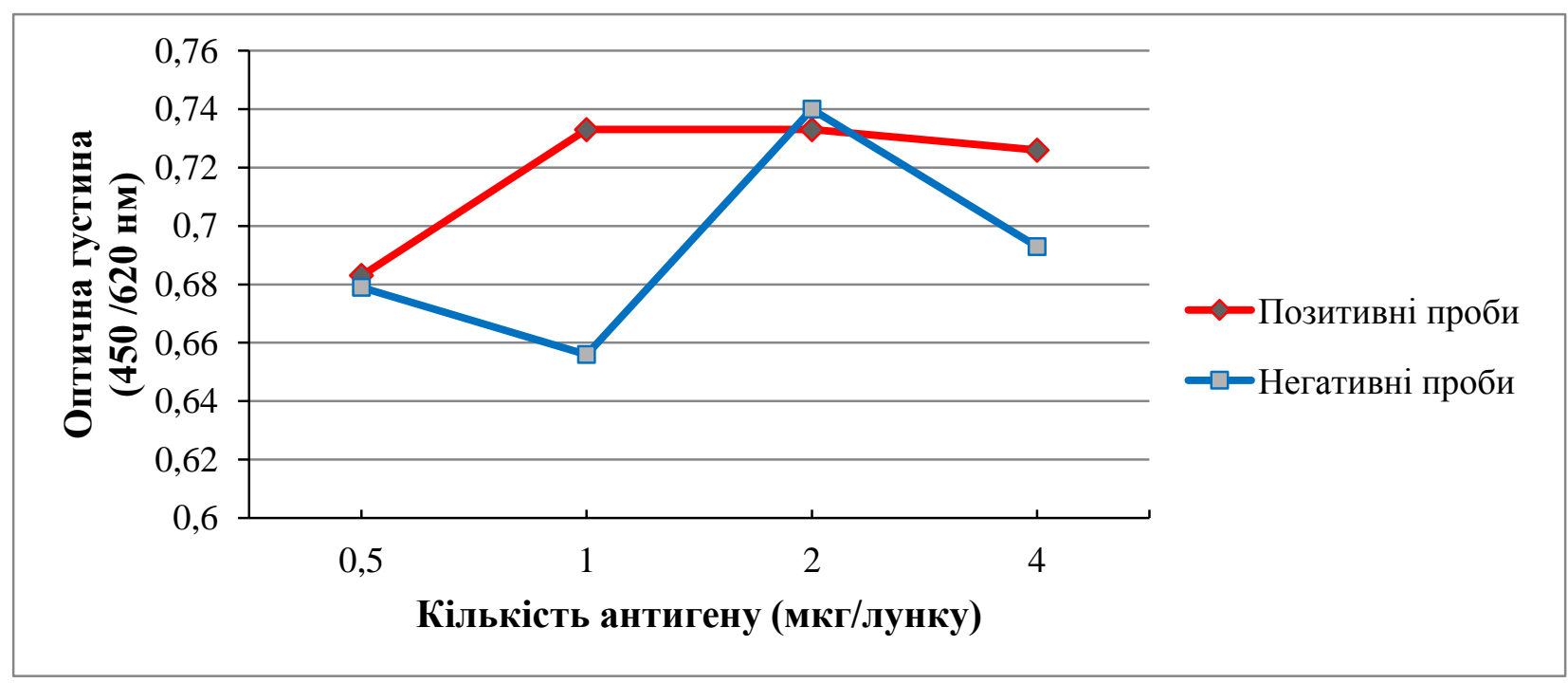

Рис. 2. Крива сорбції антигену на полістиролових мікропланшетах за використання 0,5\% розчину желатини

Аналіз результатів титрування LipL 32 показав, що оптимальна його кількість, як за використання розчину сухого знежиреного молока у якості 
блокуючої речовини, так і розчину желатини, припадала на 1 мкг/лунку. За такої кількості антигену спостерігався найвищий коефіцієнт співвідношення між значеннями оптичної густини позитивних та негативних на лептоспіроз проб сироваток крові, що складав, відповідно, 1,73 та 1,12.

Однак, за розведення зразків сироваток крові фосфатним буфером із додаванням $0,5 \%$ розчину желатини було зареєстровано високу фонову реакцію у всіх досліджених лунках мікропланшету. Зокрема, за концентрації білка 2 мкг/лунку значення оптичної густини у негативному контролі було вищим за таке у позитивному (відповідно, 0,74 о.о. та 0,733 о.о.). За використання $5 \%$ розчину сухого знежиреного молока показники ОГ негативних контролів були значно меншими, а коефіцієнти співвідношення позитивних та негативних сироваток - більшими (рис. 1, 2).

Внаслідок попередніх досліджень стосовно порівняння кон'югатів, спрямованих на різні класи імуноглобулінів, було встановлено, що кон'югат на основі рекомбінантного білка LipL 32 із пероксидазою хрону у якості ферментної мітки (спрямований на імуноглобуліни класу M та G) $є$ значно ефективнішим при діагностиці лептоспірозу тварин за такий на основі білків G Streptococcus spp. та A Staphylococcus aureus (спрямовані на антитіла класу G) [12]. Було проведено його титрування та визначення оптимального розведення проб сироваток крові для постановки ІФА із ним (табл. 1 і 2).

Таблиия 1

Результати титрування кон'югату на основі рекомбінантного білка LipL 32

\begin{tabular}{|c|c|c|c|c|c|c|c|c|}
\hline \multirow{2}{*}{$\begin{array}{c}\text { Титр сироватки } \\
\text { (МЕБ) у РМА }\end{array}$} & \multicolumn{8}{|c|}{ Розведення кон'югату } \\
\hline & $1: 10$ & $1: 100$ & $1: 500$ & $1: 1000$ & $1: 2000$ & $1: 4000$ & 1:8000 & $1: 16000$ \\
\hline $\begin{array}{l}\text { Grippotyphosa } \\
++1: 4000\end{array}$ & 3,981 & 3,429 & 2,580 & 2,430 & 1,952 & 0,833 & 0,561 & 0,211 \\
\hline $\begin{array}{l}\text { Icterohaemorrha- } \\
\text { giae }++1: 8000\end{array}$ & 3,320 & 3,111 & 2,133 & 1,721 & 1,514 & 1,128 & 0,623 & 0,114 \\
\hline $\begin{array}{l}\text { Sejroe } \\
++1: 32000\end{array}$ & 2,247 & 1,914 & 1,052 & 0,613 & 0,543 & 0,327 & 0,221 & 0,094 \\
\hline $\begin{array}{l}\text { Tarassovi } \\
++1: 16000\end{array}$ & 2,671 & 2,113 & 1,370 & 0,945 & 0,613 & 0,333 & 0,228 & 0,107 \\
\hline негат. контроль & 1,706 & 0,573 & 0,107 & 0,092 & 0,082 & 0,051 & 0,038 & 0,019 \\
\hline
\end{tabular}

Таблиия 2

Результати титрування проб сироваток крові за використання кон'югату на основі рекомбінантного білка LipL 32

\begin{tabular}{|l|c|c|c|c|c|}
\hline \multirow{2}{*}{ Титр сироватки (МЕБ) у РМА } & \multicolumn{4}{|c|}{ Оптична густина (ОГ) при 450/620 нм у розведенні } \\
\cline { 2 - 5 } & $\mathbf{1 : 2 , 5}$ & $\mathbf{1 : 5}$ & $\mathbf{1 : 1 0}$ & $\mathbf{1 : 2 0}$ & $\mathbf{1 : 4 0}$ \\
\hline Grippotyphosa ++ 1:4000 & 2,412 & 2,121 & 1,921 & 1,66 & 1,23 \\
\hline Icterohaemorrhagiae ++ 1:8000 & 2,745 & 2,192 & 1,85 & 1,441 & 0,733 \\
\hline Sejroe ++ 1:32000 & 1,721 & 1,268 & 0,922 & 0,712 & 0,512 \\
\hline Tarassovi ++ 1:16000 & 1,32 & 0,947 & 0,647 & 0,422 & 0,22 \\
\hline негат. контроль & 0,097 & 0,088 & 0,082 & 0,074 & 0,061 \\
\hline
\end{tabular}


Діапазон титрування для визначення оптимального розведення сироватки крові у ІФА був у межах від 1:2,5 до 1:40, що відповідало кількості 2,540 мкл/лунку (табл. 2). Він був підібраний з метою забезпечення досліднику зручності при подальшій постановці тест-системи, адже набрати наконечником дозатора об'єм менший за 2 мкл сироватки та сприяти його рівномірному розчиненню у 98 мкл розчину для розведення зразків дуже трудомісткий процес. У той же час, при внесенні у лунку більше 40 мкл досліджуваної сироватки крові висока ймовірність появи фонової реакції у негативних контролях. Результати титрувань наведені на рисунках 3 та 4.

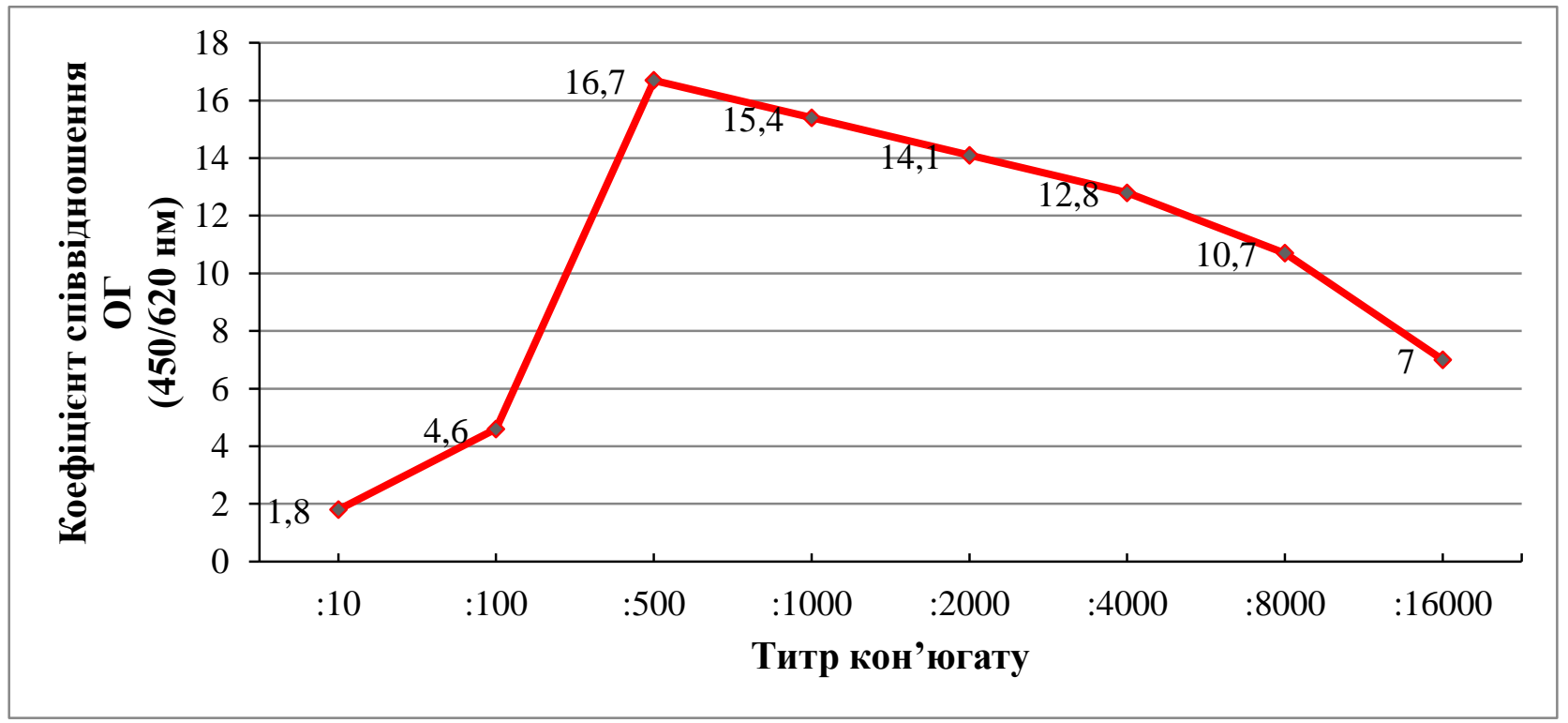

Рис. 3. Графік коефіціснтів співвідношення ОГ між позитивними та негативними пробами сироваток крові за різних титрів кон'югату

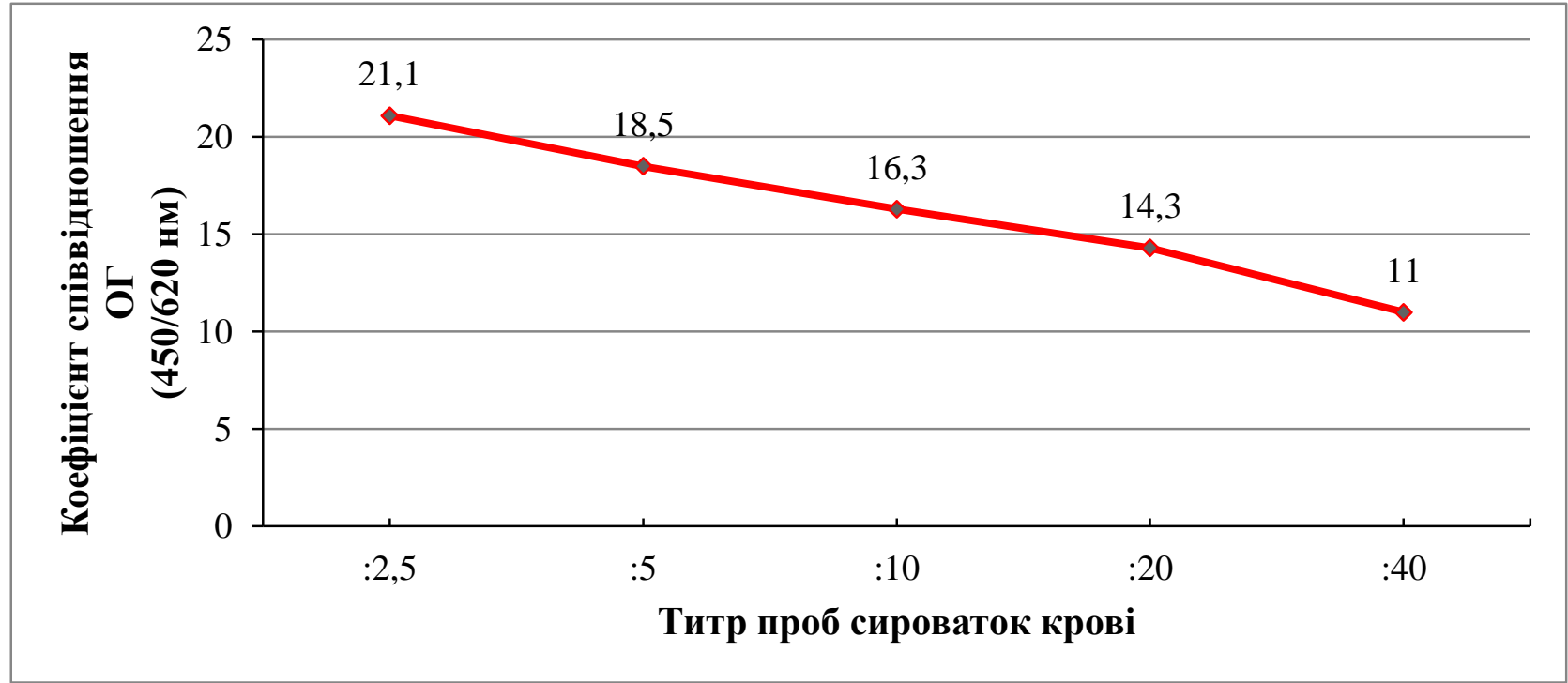

Рис. 4. Графік коефіціснтів співвідношення ОГ між позитивними та негативними пробами сироваток крові за різних титрів останніх 
Аналізуючи отримані результати титрувань, можна припустити, що найвищі коефіцієнти співвідношення ОГ між позитивними та негативними пробами сироваток крові були зареєстровані за титру кон'югату 1:500 i розведення сироватки крові 1:2,5 (40 мкл/лунку). Вони становили, відповідно, 16,7 та 21,1 (рис. 3 та 4).

Також, специфічним компонентом при розробці імуноферментного аналізу є ферментний субстрат (субстрат-хромоген). Завдяки ферментативній реакції кон'югату із субстратом за допомогою хромогену реакційна суміш забарвлюється, що дає змогу візуально або автоматично оцінювати наявність антитіл у досліджуваному матеріалі. Одними із найвисокочутливіших розчинів субстрат-хромогенів, що використовуються для постановки ІФА сьогодні, $\epsilon$ ортофенілендіамін (ОФД) та тетраметилбензидин (ТМБ), тому ми порівняли результати постановки тест-систем саме із цими сполуками. Результати порівняння чутливості розчинів субстрат-хромогенів наведені у таблиці 3.

Було встановлено, що за використання розчину ТМБ показники ОГ позитивних за РМА проб сироваток крові від усіх видів тварин та референссироваток були значно вищими, ніж за хромогену ОФД і складали, відповідно,

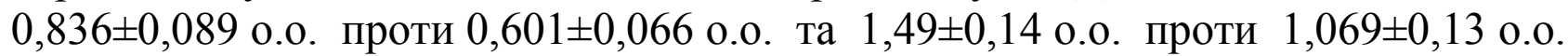
Різниця у обох випадках була вірогідною $(\mathrm{p}<0,05)$. У той же час, помітно не збільшувалися оптичні показники негативних сироваток $(0,098 \pm 0,002$ проти 0,085 $\pm 0,0017)$. Окрім того, значною перевагою ферментного субстрату ТМБ $\epsilon$ однокомпонентність, що усуває потребу у його приготуванні перед постановкою тест-систем.

Таблиця 3

\section{Результати порівняння чутливості розчинів субстрат-хромогенів ОФД та ТМБ}

\begin{tabular}{|l|c|c|c|}
\hline \multirow{2}{*}{\multicolumn{1}{c|}{ Проби сироваток крові }} & \multirow{2}{*}{$\begin{array}{c}\text { Кількість } \\
\text { проб }\end{array}$} & \multicolumn{2}{c|}{$\begin{array}{c}\text { Середні значення ОГ } \\
\text { сироваток крові, о.о. }\end{array}$} \\
\cline { 3 - 4 } & & ТМБ & ОФД \\
\hline Позитивні за РМА сироватки собак & 5 & 0,330 & 0,195 \\
\hline Негативні за РМА сироватки собак & 3 & 0,101 & 0,094 \\
\hline Позитивні за РМА сироватки свиней & 19 & 0,591 & 0,491 \\
\hline Негативні за РМА сироватки свиней & 6 & 0,096 & 0,083 \\
\hline Позитивні за РМА сироватки ВРХ & 12 & 1,436 & 0,943 \\
\hline Негативні за РМА сироватки ВРХ & 2 & 0,099 & 0,082 \\
\hline Референс-сироватки (МЕБ) & 7 & 1,49 & 1,069 \\
\hline
\end{tabular}

Таким чином, наприкінці першого етапу при розробці ІФА нами було здійснено підбір антигену, кон'югату, блокуючого реагенту та хромогенного субстрату і встановлено оптимальні їхні концентрації.

На другому технологічному етапі валідації розробленої імуноферментної тест-системи провели ії випробування та розрахунок статистичних показників у порівнянні із РМА, а саме: діагностичної чутливості i специфічності, 
прогностичних значень позитивного i негативного тестів, загальної ефективності та коефіцієнтів.

Для виконання цього етапу нами була використана внутрішньовиробнича панель сироваток крові, що нараховувала 128 позитивних (у тому числі 7 референс-сироваток (МЕБ), позитивних у високих діагностичних титрах) та 152 негативних за РМА проб сироваток крові (табл. 4).

Таблиия 4

\section{Результати випробувань тест-системи ТІФА на внутрішньовиробничій панелі проб сироваток крові}

\begin{tabular}{|c|c|c|c|c|}
\hline \multirow{2}{*}{ Вид тварин } & \multirow{2}{*}{$\begin{array}{l}\text { Виявлені титри } \\
\text { антитіл у РМА }\end{array}$} & \multirow{2}{*}{$\begin{array}{c}\text { Кількість } \\
\text { сироваток } \\
\text { крові }\end{array}$} & \multicolumn{2}{|c|}{ Оптичні показники ТІФА } \\
\hline & & & Lim & $\mathbf{M} \pm \mathbf{m}$ \\
\hline \multirow{5}{*}{ Собаки } & Негативні проби & 48 & $0,079-0,125$ & $0,101 \pm 0,00076$ \\
\hline & $\begin{array}{l}\text { Монореакція у титрі } \\
++1: 50-++1: 100\end{array}$ & 17 & $0,116-0,401$ & $0,194 \pm 0,012 * * *$ \\
\hline & $\begin{array}{l}\text { Поліреакція у титрах } \\
++1: 50-++1: 100\end{array}$ & 12 & $0,124-0,428$ & $0,266 \pm 0,015 * * *$ \\
\hline & $\begin{array}{l}\text { Монореакція у титрі } \\
++1: 500-++1: 2500\end{array}$ & 4 & $0,361-1,116$ & $0,672 \pm 0,08 * * *$ \\
\hline & $\begin{array}{l}\text { Поліреакція у титрах } \\
++1: 100-++1: 2500\end{array}$ & 4 & $0,763-3,175$ & $1,762 \pm 0,325 *$ \\
\hline \multirow{5}{*}{ Свині } & Негативні проби & 53 & $0,075-0,129$ & $0,102 \pm 0,0008$ \\
\hline & $\begin{array}{l}\text { Монореакція у титрі } \\
++1: 50-++1: 100\end{array}$ & 16 & $0,122-0,326$ & $0,182 \pm 0,0094 * * *$ \\
\hline & $\begin{array}{l}\text { Поліреакція у титрах } \\
++1: 50-++1: 100\end{array}$ & 9 & $0,136-0,425$ & $0,246 \pm 0,018 * *$ \\
\hline & $\begin{array}{l}\text { Монореакція у титрі } \\
++1: 500-++1: 2500\end{array}$ & 11 & $0,117-1,1$ & $0,508 \pm 0,035 * * *$ \\
\hline & $\begin{array}{l}\text { Поліреакція у титрах } \\
++1: 100-++1: 2500\end{array}$ & 8 & $0,681-3,138$ & $1,831 \pm 0,192 * * *$ \\
\hline \multirow{5}{*}{ BPX } & Негативні проби & 51 & $0,071-0,124$ & $0,102 \pm 0,0023$ \\
\hline & $\begin{array}{l}\text { Монореакція у титрі } \\
++1: 50-++1: 100\end{array}$ & 14 & $0,119-0,392$ & $0,212 \pm 0,013 * * *$ \\
\hline & $\begin{array}{l}\text { Поліреакція у титрах } \\
++1: 50-++1: 100\end{array}$ & 13 & $0,122-0,505$ & $0,321 \pm 0,017 * * *$ \\
\hline & $\begin{array}{l}\text { Монореакція у титрі } \\
++1: 500-++1: 2500\end{array}$ & 6 & $0,119-0,945$ & $0,483 \pm 0,05 * *$ \\
\hline & $\begin{array}{l}\text { Поліреакція у титрах } \\
++1: 100-++1: 2500\end{array}$ & 7 & $0,823-3,345$ & $1,647 \pm 0,239 * * *$ \\
\hline $\begin{array}{c}\text { Сироватки } \\
\text { МЕБ } \\
\end{array}$ & $\begin{array}{l}\text { Монореакція у титрі } \\
++1: 4000-++1: 32000\end{array}$ & 7 & $0,698-2,583$ & $1,52 \pm 0,139$ \\
\hline
\end{tabular}

Примітки: * $\mathrm{p}<0,05 ; * * \mathrm{p}<0,01 ; * * * \mathrm{p}<0,001$

Як видно із таблиці 4, у пробах сироваток крові від собак, свиней та ВРХ показники оптичної густини збільшувалися із наростанням титрів лептоспірозних антитіл у РМА. При цьому, у більшості випадків різниця між ними була високо вірогідною $(p<0,001)$. 
У той же час, ліміти та середні значення ОГ у межах кожної із груп сироваток крові були подібними між собою у всіх перелічених видів ( $p<0,5$; $<0,1)$. Різниця була вірогідною лише між зразками від свиней і ВРX та ВРX i собак (відповідно, $p<0,01$ та $p<0,05$ ), хоча діапазони лімітів значною мірою співпадали. Виходячи із отриманих результатів, нами було прийнято рішення проводити розрахунок статистичних показників імуноферментної тест-системи одночасно по значенням ОГ проб від усіх трьох видів тварин та референссироваток (МЕБ).

Перед початком статистичних розрахунків необхідно було максимально точно визначити межі показників ОГ, що відповідали істинним та хибним. 3 цією метою ми скористалися разрахунком «сut-off» («відсікання»), на основі якого було сформовано таблицю 5.

Табличя 5

Результати порівняння розробленої тест-системи ІФА із РМА

\begin{tabular}{|c|c|c|}
\hline Позитивні та негативні проби & \multicolumn{2}{|c|}{ Позитивні та негативні проби за РМА } \\
\cline { 2 - 3 } сироваток крові за ІФА & РМА+ & PMA- \\
\hline IФА+ & 115 & 5 \\
\hline IФА- & 13 & 147 \\
\hline
\end{tabular}

На завершальному етапі проводили розрахунок статистичних показників тест-системи. Так, ऑï чутливість визначали відношенням кількості істиннопозитивних сироваток панелі, взятих для аналізу, до їх суми з кількістю хибнонегативних значень, виражених у відсотках:

115

$$
\mathrm{D}-\mathrm{SN}=\frac{1}{(115+13)} \times 100=89,8 \% \text {. }
$$

Специфічність тест-системи визначали відношенням кількості істиннонегативних сироваток панелі, взятих для аналізу, до їх суми з кількістю хибнопозитивних значень, виражених у відсотках:

$$
\mathrm{D}-\mathrm{SP}=\frac{147}{(147+5)} \times 100=96,7 \% \text {. }
$$

Загальну ефективність розраховували за відношенням суми істиннопозитивних та істинно-негативних сироваток панелі, взятих для аналізу, до їх суми із хибно-позитивними та хибно-негативними значеннями, виражених у відсотках:

$$
\mathrm{Ef}=\frac{(115+147)}{(115+5+147+13)} \times 100=93,6 \%
$$

Окрім цього був проведений розрахунок додаткових показників ефективності, а саме: прогностичних значень позитивного (95,8\%) та негативного тестів $(91,9 \%)$, індексу Йоудена $(0,865)$, а також коефіцієнтів ймовірності позитивного $(27,2)$ і негативного результатів $(0,105)$. 


\section{Висновки та перспективи подальших досліджень:}

1. Здійснено підбір основних компонентів для постановки IФА на лептоспіроз та визначено їх оптимальні концентрації і титри.

2. Встановлено, що чутливість розробленої тест-системи ІФА є меншою, ніж іï специфічність (89,8 \% проти 96,7 \%), проте загальна ефективність цього методу знаходиться на високому рівні і становить 93,6 \%.

3. Прогностичні значення, що вказують на відсоток проб сироваток крові від тварин, правильно класифікованих тестом на позитивні чи негативні, $\epsilon$ високими і складають, відповідно, 95,8 \% та 91,9 \%.

Перспективи подальших досліджень полягають у впровадженні розробленої тест-системи ІФА та їі використанні для діагностики лептоспірозу серед тварин на території України.

\section{СПИСОК ЛІТЕРАТУРИ}

1. Adler B. Leptospira and leptospirosis / B. Adler, A.P. Moctezuma // Veterinary Microbiology - 2010. - Vol. 27. -P. 287-296.

2. Уховський В.В. Порівняльна характеристика сучасних методів лабораторної діагностики лептоспірозу $\mathrm{c} / \Gamma$ тварин та перспектива розробки дот-ІФА 3 метою іiі удосконалення / В.В. Уховський, О.О. Кучерявенко, А.В. Пискун // Бюллетень «Ветеринарна біотехнологія». - 2013. - № 23. - С. 259-260.

3. Корнієнко Л.Є. Хронічні інфекційні хвороби тварин / Л.Є. Корнієнко, В.О. Бусол, В.В. Недосєков [та ін.]. - Біла Церква, 2009. - 291 с.

4. Cinco M. Evaluation of an immunoenzymatic test (ELISA) for the diagnosis of leptospirosis in Italy / M. Cinco, D. Balanzin, E. Banji // European Journal of Epidemiology 1992. - Vol. 8. - P. 677-682.

5. Wautkins S.A. Leptospira in ELISA in the Clinical Microbiology Laboratory / S.A. Wautkins, W.J. Zochowski // London: Public Health Laboratory Service - 1990. - P. 225-237.

6. Kurstak E. Progress in enzyme immunoassys: production of reagents, experimental design, and interpretation / E. Kurstak // Bulletin of the World Health Organization - 1985. Vol. 63 (4). - P. 793-811.

7. Іванська Н.В. Практичний посібник по роботі з імуноферментною тест-системою для визначення антитіл проти лептоспір «ІФА-лептоспіроз-ВРХ» / Н.В. Іванська, О-й.О. Кучерявенко, О-р.О. Кучерявенко [та ін.] - К., 2003. - 28 с.

8. Tokuda H. Biogenesis of outer membranes in Gram-negative bacteria / H. Tokuda // Bioscience, Biotechnology and Biochemistry. - 2009. - Vol. 73(3). - P. 465-473.

9. Murray G.L. Major surface protein LipL32 is not required for either acute or chronic infection with Leptospira interrogans / G.L. Murray, A. Srikram, D.E. Hoke [et al.] // Infection and Immunity. - 2009. - Vol. 77(3). - P. 952-958.

10. Sharma R. Application of rapid dot-ELISA for antibody detection of leptospirosis / R. Sharma, U. Tuteja, R. Khushiramani [et al.] // Journal of Medical Microbiology. - 2007. Vol. 56 (6). - P. 873-874.

11. Bomfim M.R. Evaluation of the recombinant LipL32 in enzyme-linked immunosorbent assay for the serodiagnosis of bovine leptospirosis / M.R. Bomfim, M.C. Koury // Veterinary Microbiology. - 2005. - Vol. 109. - P. 89-94.

12. Пискун А.В. Підбір оптимального кон'югату для постановки імуноферментного аналізу на лептоспіроз / А.В. Пискун // Бюллетень «Ветеринарна біотехнологія». - 2015. № 26. - C. 156-163. 


\section{РАЗРАБОТКА ИММУНОФЕРМЕНТНОЙ ТЕСТ-СИСТЕМЫ ДЛЯ} ДИАГНОСТИКИ ЛЕПТОСПИРОЗА У ЖИВОТНЫХ / ПискуН А.В., Уховский В.В., Алексеева Г.Б., Спиридонов В.Г., Пискун О.Е.

В статье представлены результаты относительно валидации твердофазной иммуноферментной тест-системь для диагностики лептоспироза среди собак, свиней и КРС, которая была разработанной на базе лаборатории лептоспироза сельскохозяйственных животных с музеем микроорганизмов Института ветеринарной медицины (ИВМ НААН) $и$ Украинской лаборатории качества и безопасности продукции АПК (УЛКБП АПК).

В ходе валидаџии нами было осуществлено несколько технологических этапов. На первом из них проводили подбор и определяли оптимальные концентрачии и титры основных компонентов ИФА (антигена, иммуноферментного конъюгата, ферментного субстрата $u$ блокирующего вещества), а на втором - осуществляли статистическую обработку полученных результатов после испытания ИФА на внутрипроизводственной панели проб сывороток крови.

Ключевые слова: лептоспироз, реакция микроагглютинации, твердофазный иммуноферментный анализ, валидация, титр.

\section{THE DEVELOPMENT OF ENZYME-LINKED IMMUNOSORBENT ASSAY (ELISA) FOR DIAGNOSTICS OF LEPTOSPIROSIS IN ANIMALS / Pyskun A.V., Ukhovskyi V.V., Aliekseieva G.B., Spiridonov V.G., Pyskun O.O.}

Introduction. The wide spectrum of symptoms makes the clinical diagnosis on leptospirosis undependable. The laboratory diagnosis of leptospirosis, a prerequisite for treatment, is usually achieved either by isolation of the causative agents or by serological indicating of antibodies. The microscopic agglutination test (MAT) is the reference test for diagnosis and detects antibodies at serovar levels. MAT has many advantages, but there are significant disadvantages. The maintenance of cultures and use of live organisms creates a risk of laboratory-acquired infection. Therefore, several methods have been developed for leptospirosis diagnostics as an alternative to MAT, among which IgM ELISA is the most promising as detects genus-specific antibodies.

The goal of the work was to develop a modification of ELISA for the diagnosis of leptospirosis in animals.

Materials and methods. During the validation, we have conducted several technological stages. The first one was performed by selection and determination the optimal concentration and titres of ELISA main components (antigen, enzyme conjugate, enzyme substrate and blocking substance) and the second one was in statistical analysis of the results after testing ELISA on the reference panel of sera blood samples.

Results of research and discussion. As the antigen was used recombinant protein LipL 32, which is a modified compound one of the major outer membrane lipoprotein of pathogenic Leptospira species.

To determine the optimal dose of sensitizing antigen, we conducted its sorption within 0.5$4 \mu \mathrm{l}$ volume. At the same time we have tested substances that eliminate the nonspecific interaction of antibodies with antigen - edible gelatin and skimmed milk powder (respectively, 0.5\% and 5\% solutions). Analysis of titration showed that the optimum amount of LipL 32 in both cases was $1 \mu$ l. However, it was registered high background reaction in all investigated wells of microplate after blood sera samples dilution by phosphate buffer with $0.5 \%$ gelatin solution. When $5 \%$ solution of skimmed milk was used, the indicators of optical density in negative controls were much smaller, and correlation coefficients of positive and negative sera were higher.

The highest correlation coefficients of optical density between positive and negative samples of blood sera were registered in its titer 1/500 and dilution of sera 1/2.5 (40 $\mu$ l volume).

A comparison enzyme substrates showe, that the indicators of optical density in positive samples blood sera by MAT were significantly higher when using TMB solution, than indicators by using OFD chromogen, respectively, $0.836 \pm 0.089$ o.d. against $0.601 \pm 0.066$ o.d. The difference of 
optical values in both cases was significant $(p<0,05)$. At the same time, the optical indicators of negative blood sera samples by MAT were not significantly different in both cases (0.098 \pm 0.002 o.d. against $0.085 \pm 0.0017$ o.d.).

Conclusions. 1. Selection and determination the optimal concentration and titres of ELISA main components (antigen, enzyme conjugate, enzyme substrate and blocking substance) were conducted.

2. Established that the sensitivity of the developed ELISA is less than its specificity $(89.8 \%$ against 96.7\%), but overall efficiency of this method is high and equals 93.6\%.

3. Prognostic values, indicating the percentage of blood serum samples from animals correctly classified by ELISA to positive or negative, are high and constitute, respectively, 95.8\% and $91.9 \%$.

Keywords: Leptospirosis, microscopic agglutination test, enzyme-linked immunosorbent assay, validation, titer.

\section{REFERENCES}

1. Adler, B., \& Moctezuma, A.P. (2010). Leptospira and leptospirosis. Veterinary Microbiology, 27, 287-296.

2. Ukhovskyi, V.V., Kucheryavenko, O.O., \& Pyskun, A.V. (2013). Porivnyalna harakterystyka suchasnyh metodiv laboratornoyi diahnostyky leptospirozu s/h tvaryn ta perspektyva rozrobky dot-IFA z metoyu yiyi udoskonalennya [Comparative characteristics of modern methods laboratory diagnosis of leptospirosis farm animals and development perspective dot-ELISA for this improvement]. Byulleten «Veterinarna biotehnologiia»-Bulletin of Veterinary biotechnology, 23, 259-260 [in Ukrainian].

3. Korniyenko, L.E., Busol, V.O., Nedosekov, V.V. et al. (2009). Hronichni infekcijni hvoroby tvaryn [Chronical infectious diseases of animals]. Bila Tserkva [in Ukrainian].

4. Cinco, M., Balanzin, D., Banji, E. (1992). Evaluation of an immunoenzymatic test (ELISA) for the diagnosis of leptospirosis in Italy. European Journal of Epidemiology, 8, 677-682.

5. Wautkins, S.A., \& Zochowski, W.J. (1990). Leptospira in ELISA in the Clinical Microbiology Laboratory. London: Public Health Laboratory Service, 225-237.

6. Kurstak, E. (1985). Progress in enzyme immunoassys: production of reagents, experimental design, and interpretation. Bulletin of the World Health Organization, 63 (4), 793-811.

7. Ivanska, N.V., Kucheryavenko, O-yO., Kucheryavenko, O-rO. et al. (2003). Praktychnyj posibnyk po roboti $z$ imunofermentnoyu test-systemoyu dlya vyznachennya antytil proty leptospir "IFA-leptospiroz-VRH» [Practical guide to working with the enzyme-linked immunosorbent assay for the detection of antibodies against Leptospira "ELISA-Leptospirosis-cattle"]. Kyiv [in Ukrainian].

8. Tokuda, H. (2009). Biogenesis of outer membranes in Gram-negative bacteria. Bioscience, Biotechnology and Biochemistry, 73(3), 465-473.

9. Murray, G.L., Srikram, A., Hoke, D.E. et al. (2009). Major surface protein LipL32 is not required for either acute or chronic infection with Leptospira interrogans. Infection and Immunity, 77(3), 952-958.

10. Sharma, R., Tuteja, U., Khushiramani, R. et al. (2007). Application of rapid dot-ELISA for antibody detection of leptospirosis. Journal of Medical Microbiology, 56(6), 873-874.

11. Bomfim, M.R., \& Koury, M.C. (2005). Evaluation of the recombinant LipL32 in enzyme-linked immunosorbent assay for the serodiagnosis of bovine leptospirosis. Veterinary Microbiology, 109, 89-94.

12. Pyskun, A.V. (2015). Pidbir optymalnoho konyuhatu dlya postanovky imunofermentnoho analizu na leptospiroz [Selection of optimal conjugate for the enzyme-linked immunosorbent assay against Leptospirosis]. Byulleten «Veterinarna biotehnologiia»-Bulletin of Veterinary biotechnology, 26, 156-163 [in Ukrainian]. 